POLIIICAL ECONOMY RESEARCH INSTITUTE

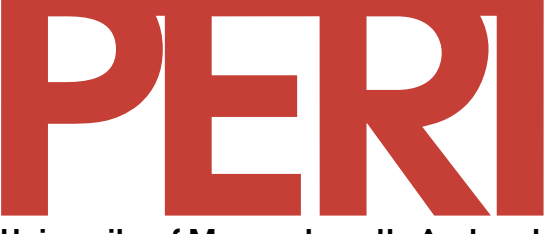

University of Massachusetts Amherst

\title{
Extractive Reserves: Building Natural Assets in the Brazilian Amazon
}

\author{
Anthony Hall
}

2004

10th floor Thompson Hall University of Massachusetts Amherst, MA, 01003-7510 Telephone: (413) 545-6355 Facsimile: (413) 545-2921

Email:peri@econs.umass.edu Website:

http://www.umass.edu/peri/

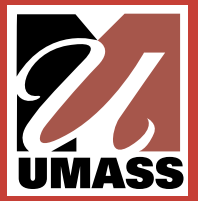




\section{Extractive Reserves:}

\section{Building Natural Assets in the Brazilian Amazon}

Anthony Hall

Reader in Social Planning in Developing Countries

Department of Social Policy

London School of Economics and Political Science 


\section{Introduction}

Amazonia possesses the world's largest remaining area of tropical rainforest $\left(3.5\right.$ million $\left.\mathrm{km}^{2}\right)$. Despite three decades of settlement and intensive development, the forest is still relatively intact compared with similar areas elsewhere. The region is an increasingly important source of natural assets for both regional and national economic growth, and provides livelihood support to a population of several million. In addition, the Amazon supplies key environmental services in terms of the conservation of biological diversity, climate regulation, and watershed management, as well as sequestering an estimated ten percent of global carbon emissions.

Traditional forest-dwelling populations such as rubber tappers and indigenous groups have been stewards of the natural resource base in Amazonia through their use of non-destructive technologies at low demographic densities. As the frontier has advanced, however, they have come under growing peril from rent-seeking interests that threaten to destroy the forest and people's livelihoods with it. Official policies have tended to reward such predatory forms of occupation through generous subsidies, while ignoring the ecological services provided by local populations. Brazil's rubber tappers were the first social group to pose a major challenge to this 'development' model. Making a pre-emptive strike against cattle ranchers and land speculators, they have appropriated for themselves large areas of forest at risk of becoming 'open access' to all comers seeking profits. They defended their lands, and proposed a strategy to consolidate their hold by setting up 'extractive reserves' - conservation areas where local communities can harvest non-timber forest products, such as latex and nuts.

\section{Rubber tappers and indigenous groups - longstanding stewards of the Amazon - have come under growing peril from rent-seeking interests that threaten to destroy the forest and people's livelihoods with it.}

The 'extractive reserve' model attempts to reconcile objectives previously considered incompatible by mainstream policy-makers; namely, the protection and conservation of forests alongside their sustainable economic use for the benefit of local populations. It aims to achieve this through a strategy of joint management involving local communities, representative bodies, government institutions, non-governmental organizations (NGOs) at domestic and international levels, aid donors, and the private sector. It is hoped that over time these extractive reserves will build economic strength, managerial competence, and social unity. In the long run, however, the viability of the reserves may require that locally generated income from the sale of forest products be supplemented by the establishment of fiscal and other revenue transfer mechanisms to reward these guardians of the forest for the environmental and social benefits they produce. 


\section{People and Nature in Amazonia}

Ever since the first colonial explorers set foot in Brazilian Amazonia during the sixteenth century, the region has been perceived as an infinite resource pool that could be tapped at will regardless of the consequences. Perhaps because of its sheer size $\left(5\right.$ million $\mathrm{km}^{2}-$ see Figures 1 and 2) and its vast natural wealth, Brazil's Amazon region effectively has been treated as an open-access resource that can be exploited unashamedly to serve a range of economic, social, and geopolitical interests, both public and private.

As Slater (2002) notes, images of the Amazon have been created and manipulated by outsiders bent on appropriating its natural assets for their own benefit. The Conquistadors portrayed it as a hostile wilderness inhabited by warrior-like women, promptly named 'Amazons' after the Greek legend. Following the military coup of 1964, Brazil's generals projected images of the region as an uninhabited frontier, 'empty spaces' urgently in need of occupation in the name of national integration and development. Conservationists similarly have tended to ignore the long-standing presence of indigenous populations and their role in managing what is in many respects an 'anthropogenic forest' rather than the 'virgin' rainforest of popular myth. To some extent, the assumption of a demographic vacuum was based on sheer ignorance, but it was also convenient in that it allowed outsiders to ignore the interests and rights of pre-existing occupants in their search for land, forest, and mineral assets to exploit.

Until the 1960s, Brazil's Amazonia remained relatively isolated, being considered a distant and primitive backwater of little relevance to the nation's quest for economic progress and industrial power. Its rural population comprised some 100,000 Amerindians (the descendants of an original indigenous population estimated at several million at the time of the Conquest) as well as other 'traditional' mixed-race populations, known locally as caboclos, formed over the centuries through the mixing of indians with a small but steady stream of white and Afro-Brazilian immigrants to Amazonia. Their livelihoods were (and, to a large degree, still are) based on a combination of 'extractivism' (the harvest of non-timber forest products), fishing, and subsistence farming. From the late 1960s, these groups were complemented by waves of smallfarmer settlers from northeastern and southern Brazil, attracted to Amazonia by government promises of land. According to the 2000 census, Brazilian Amazonia's rural population of almost four million (of 13 million in the region as a whole) includes about 200,000 indigenous people, thanks to an annual growth rate in recent decades of 3.5 percent, three times the national average (ISA 2000). Caboclos probably account for a further million-plus (or some 25 percent), and newer settlers now account for the remaining majority in the countryside.

\section{Developing' the Amazon}

During the Brazilian 'economic miracle' years of the 1970s, when Amazonia was subjected to intensive settlement, traditional groups were viewed by government authorities and most urbanites with indifference or outright hostility. At best they were perceived as vestiges of a bygone age to be tolerated for their exotic value, and at worst as obstacles to modernization who had to be dragged into the twentieth century or, if necessary, eliminated. Generations of social, 
Fig. 1: Map of Brazil - Amazonia

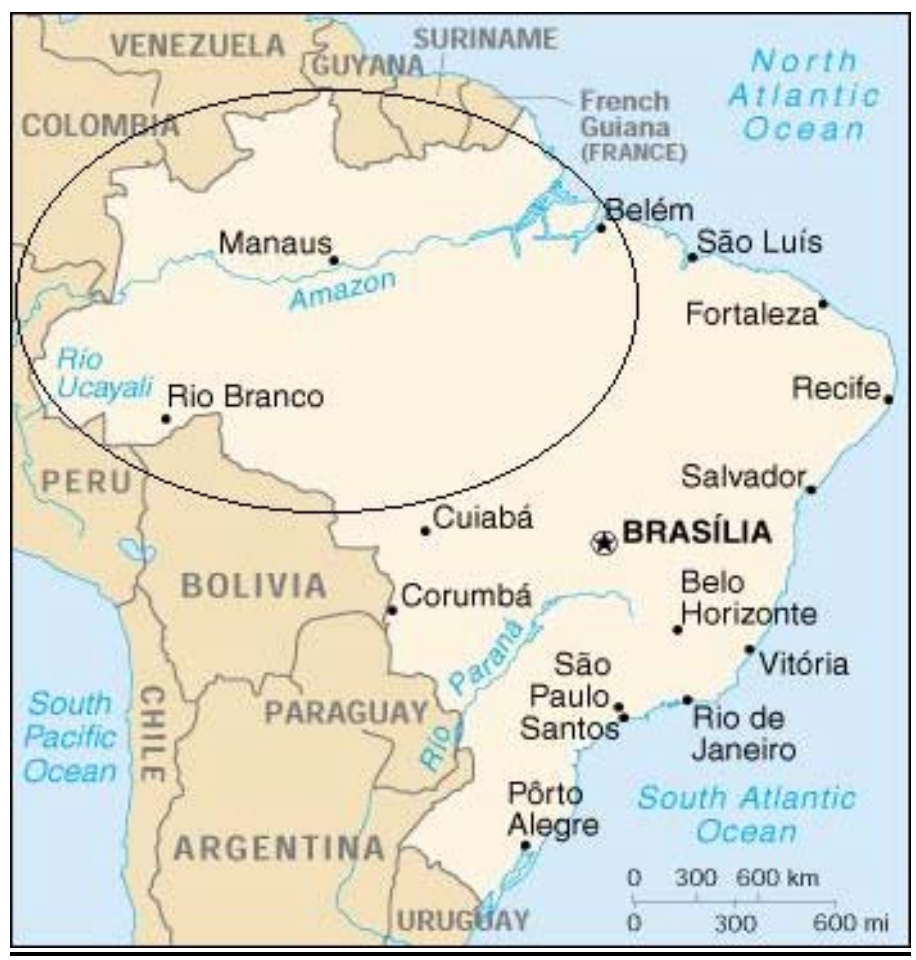

Source: http;//brazilcanada.enoreo.on.ca/schools/brazilmap.htm

Figure 2: Western Europe Superimposed on Brazilian Amazonia

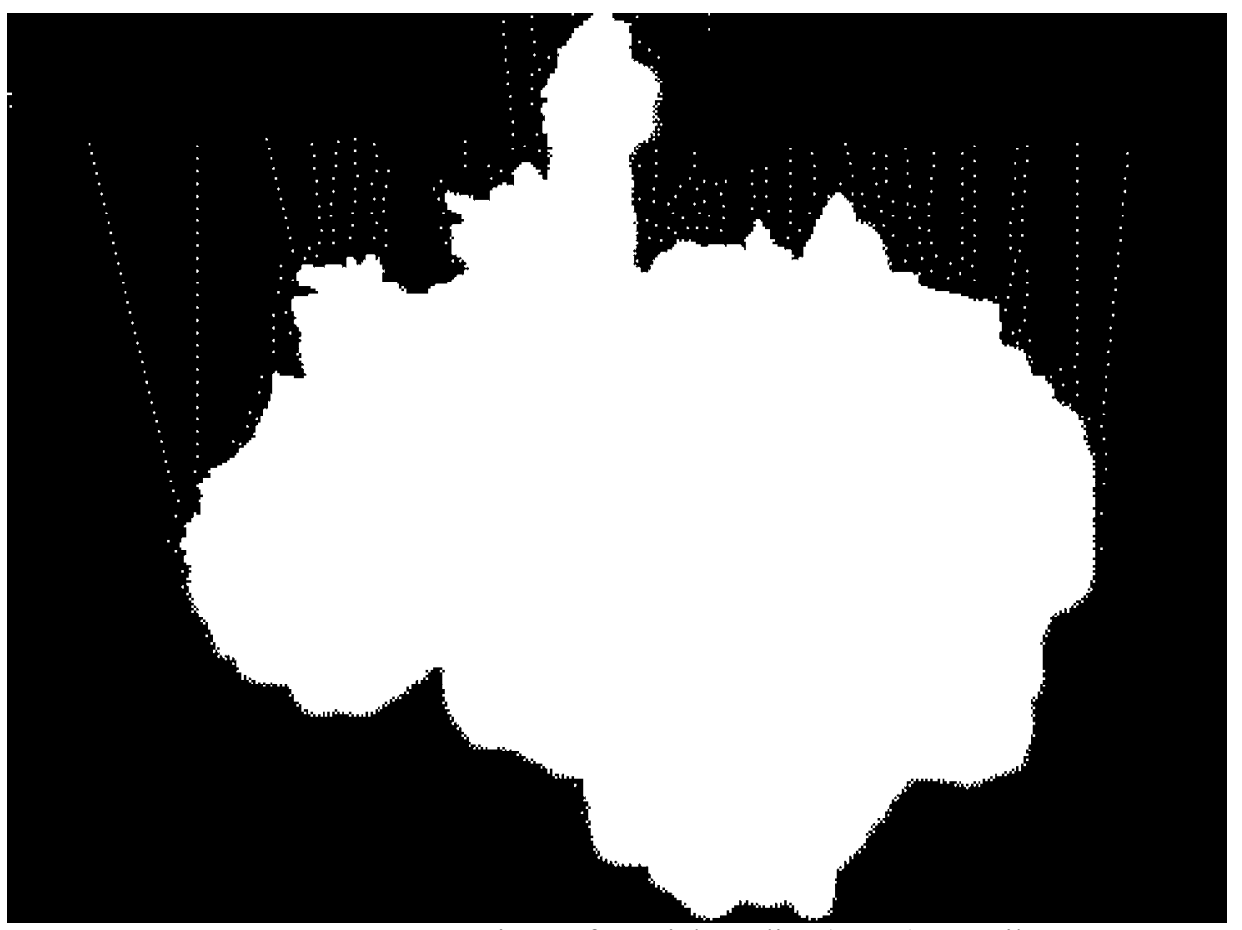

Source: Institute of Spatial Studies (INPE), Brazil. 
cultural, and racial prejudice had portrayed Amazonia's traditional populations as 'poor', 'inferior', 'backward', and a burden on society. These notions were reinforced when Brazil's military regime, which came to power in the coup of 1964, began the process of 'integrating' Amazonia into the mainstream of economic and political life. Official development policies at the time, heavily influenced by thinking emanating from Brazil's military college, adopted a nationalistic and expansionist strategy with regard to Amazonia to advance a number of economic, social, and geopolitical goals (see Hall 1989; Gross 1990; Becker and Egler 1992; Schminck and Wood 1992).

First, investments in large-scale commercial livestock, agriculture, logging, mining, and infrastructure enterprises were expected to bring rapid economic progress to the region and generate valuable export revenues. Underpinned by then-dominant modernization and 'growth pole' theories, with their 'trickle-down' assumptions, it was thought that such a strategy would benefit all sectors of the population. So-called 'primitive' technologies such as extractivism were considered an anachronism by policy-makers, and received no official support. Instead resources were directed at the 'modern' sector. Generous government inducements were given to entrepreneurs, and especially political allies from southern Brazil, as well as to foreign corporations such as Volkswagen. From 1971 to 1987, a staggering US\$5 billion in tax credits were granted for Amazonian cattle ranching alone (Schneider 1992; Mahar 1989). In addition, vast subsidies were used to encourage large-scale mining of iron ore, bauxite, and other minerals in schemes such as the Greater Carajás program (Hall 1989). ${ }^{1}$

A second driving force behind the settlement of Amazonia was social rather than economic. The government used the region as a 'safety-valve' in an attempt to create employment and ease social tensions elsewhere. The polarization of land ownership and growth of land conflicts between peasant farmers and estate owners had created increasingly volatile situations in various parts of the country. In North-East Brazil, the spread of subsidized cattle ranching within an already volatile property structure led to violent confrontations over access to land. Furthermore, periodic droughts drove landless and land-poor farmers to seek livelihoods elsewhere (Hall 1978). In southern Brazil, the rapid extension of large-scale mechanized wheat and soybean production for export made family farming increasingly difficult. Many small farmers were unable to compete with the larger subsidized producers and were driven out of business. Some left farming altogether, but, encouraged by government promises of support, many others were attracted to Amazonia in the early 1970s. The government undertook aggressive publicity campaigns to promote official colonization schemes along the newly opened Transamazon Highway and in the Polonoroeste program in the north-western state of Rondônia, even providing free bus and air transportation. Economic and social infrastructural support in these schemes fell far short of the original promises, however, leading to high rates of farmer turnover, internal migration, and deforestation (Hall 1989; Mahar 1989). Following in the wake of officially sponsored settlers, many more poor farmers spontaneously settled in Amazonia.

A third major factor that underpinned official strategies to penetrate and settle Amazonia was geopolitical. The strongly technocratic federal state, under the direction of the generals, was anxious to contain the power of regional oligarchs who, it was thought, could resist change and undermine central government attempts to modernize Amazonia. Furthermore, military occupation of the region was seen as important to help contain the dangers of guerrilla 
insurgency, as occurred in the Araguaia region of eastern Amazonia in the early 1970s. Hard-line nationalists within the armed forces and Ministry of Foreign Affairs also considered it essential to boost Brazil's border defenses in order to consolidate the country's strategic domination of the Amazon Basin and defend against possible foreign incursions (Becker 1982; Dreifuss 2000).

\section{Deforestation and Conflict}

Official Amazon development policy has had major implications for the use and abuse of the region's natural assets. The level of deforestation, arguably the most important indicator of ecological degradation, has increased steadily. According to government statistics, in 1970 total forest loss stood at just 2.4 percent in Brazilian Amazonia, rising to more than 10 percent by 1993 and 15 percent in 2001. Recorded annual deforestation rates have fluctuated from an average of $21,000 \mathrm{~km}^{2}$ during the $1980 \mathrm{~s}$ to a peak of $29,000 \mathrm{~km}^{2}$ in $1994-95$, and an average of $18,000 \mathrm{~km}^{2}$ a year since then (INPE, 2000). Research suggests that forest fires and illegal logging damage a further $15,000 \mathrm{~km}^{2}$ of forest every year, bringing the annual total to over $30,000 \mathrm{~km}^{2}$ (Nepstad et al. 1999). Furthermore, increased fragmentation, in which the forest is reduced to isolated patches rather than a contiguous expanse, substantially worsens biodiversity loss due to the inability of small areas to support populations of flora and fauna (Lovejoy 2000). Although the various causal factors overlap, it is generally accepted that cattle ranching has been directly responsible for around 60 percent of overall forest loss, small-scale farming for about 30 percent, and commercial logging and mining for the remaining ten percent (Mahar 1989; Fearnside 1993). Destruction has been concentrated along the so-called 'deforestation arc' on the southern and eastern borders of Amazonia, but its impacts have been felt throughout the region.

\section{The level of deforestation has increased steadily.}

From the inception of Brazil's official 'assault on the Amazon' (Bourne 1978), political and military leaders assumed that 'modernizing' initiatives would generate economic progress with a minimum of ecological and social disruption. Little regard was given to the compatibility of land-use models imported from northeast and southern Brazil with the circumstances of Amazonia. Slash-and-burn farming, for example, although viable at low population densities, became unsustainable and a threat to the rainforest ecosystem in significant sections of the Brazilian Amazon following large-scale settlement by farmers from north-eastern and southern Brazil (Fearnside 1990). Similarly, cattle ranching on Amazonia's generally poor soils led to rapid land degradation and soil erosion, reducing the life expectancy of pastures to a few years (Hecht 1985).

Livestock development, fueled by huge government subsidies that encouraged property speculation, exacerbated land conflicts between cattle barons on the one hand and small farmer colonists and resident traditional populations on the other. The result was a dramatic increase in land struggles and displacements of small producers, and a sharp rise in the death toll from such conflicts, with over 1000 fatalities from 1980-86 alone (Branford and Glock 1985; Hall 1989). 
Since the mid-1990s, Brazil's 'Movement of the Landless' (Movimento dos Trabalhadores Rurais Sem Terra - MST) has become increasingly active in Amazonia as small farmers have struggled to secure permanent access to land (Branford and Rocha 2002). Land occupations have on the whole been relatively peaceful, but violence is never far below the surface. For example, in 1995 military police killed 14 people during an occupation at Corumbiara in the western state of Rondônia. In April 1996, at Eldorado do Carajás in the eastern Amazon state of Pará, military police massacred 19 members of the MST during a demonstration.

The outside observer could be forgiven for thinking that such conflicts reflect a land shortage in the Amazon. With some five million $\mathrm{km}^{2}$ (including 3.5 million $\mathrm{km}^{2}$ of rainforest) and covering 60 percent of national territory, land itself is plentiful. What is in shorter supply is land close to roads and highways. The more accessible the land, the higher its price and the greater the competition over tenure. Just 17 percent of land in the Amazon is officially classified as 'occupied' under private property, and many of these titles are fraudulent (INCRA 1997). Ten percent (50 million hectares) of Brazil's Amazon region is in about 120 protected areas of various kinds, while a further 19 percent (98 million hectares) is in some 366 indigenous reserves (Ramos and Capobianco 1996). The remaining 54 percent is categorized as state land under the jurisdiction of the federal government. The one million-plus Amazonians who engage in extractive activities such as rubber tapping, nut gathering, and fishing do so largely within protected areas and on state-owned land. There is also a small but growing number of private landowners adopting extractivist and related agroforestry technologies, as discussed below.

The most intensive processes of land conflict and deforestation occur in easily accessible areas close to highways, as in southern Pará and Rondônia. Over 60 percent of forest loss occurs within a $100 \mathrm{~km}$ corridor along major roads in the region. From 1992-98, 105 million hectares (an area four times the size of the UK) was incorporated within the agricultural frontier, much of it in large properties, producing soybean for export and livestock. Private distribution in Amazonia is heavily skewed, reflecting the polarized land ownership structure in Brazil generally. Just 53 properties of over 100,000 hectares account for 30 percent of land ownership in the region. Properties in the Amazon of over 1,000 hectares account for five percent of farms but 76 percent of the land, while properties of less than 100 hectares make up 62 percent of farms and six percent of the land (INCRA 1997).

Small and poorer producers struggling for survival at the margins have in many respects paved the way for larger settlers as they have opened up the frontier. For example, small farmers have commonly entered into agreements in which they are allowed by larger landowners to deforest and cultivate land for a limited period before moving on to allow the owner to sow pasture and raise cattle. Similarly, small settlers often cede logging rights on their land to commercial companies in exchange for the bulldozing of access roads.

Deforestation adversely impacts upon the provision of key environmental services, including the maintenance of biodiversity, climate control, soil conservation, and watershed management. In addition, and most critically for the present analysis, deforestation undermines the position of traditional populations such as extractivists and indigenous groups whose livelihoods depend to varying degrees on intact forests. Indigenous and traditional groups have suffered at the hands of both large and small settlers, as newcomers have occupied land, often with little or no concern 
for customary or legal property rights. Environmental policy in Brazil during the 1970s and 1980s was limited to the protection of designated conservation areas in which human habitation was either prohibited, as in national parks and ecological stations, or carefully controlled, as in national forests (Hall 2000). There was no concern for incorporating local livelihoods into environmental policy instruments.

As the livestock frontier advanced westwards into the Amazon, the rubber tappers of southern Acre state (situated close to the Bolivian border) found themselves increasingly under threat, their interests completely ignored by the State. Their struggle for survival, described in the next section, led to the establishment of extractive reserves as an innovative, sustainable land-use model, and a potential precursor to a range of environmental policy instruments that would attempt to involve directly local populations in the process of resource governance.

\section{The History and Struggle of Brazil's Rubber Tappers}

During the late nineteenth century, extraction of latex from Brazil's native rubber tree expanded in response to growing world demand for rubber, especially from the new automobile industry following discovery of the vulcanization process (Hall 1996, 1997a). Businessmen set up rubber estates throughout Amazonia, especially in the states of Amazonas, Rondônia, and Acre, which was annexed from Bolivia in 1903. Poor peasant farmers fleeing the periodic droughts of northeast Brazil were brought in to make up the labor force. After the collapse of the rubber boom in 1912 as the result of competition from Malay plantation rubber (a venture initiated by the British with seedlings taken from Brazil), the rubber economy fell into decline. Estates were abandoned by their owners leaving their former laborers to eke out a living as best they could. By the 1960s, many of the latter had become small producers, operating autonomously on their respective areas of forest throughout which rubber trees were scattered. These rubber tappers held no property titles, but they exercised effective usufruct rights. They were linked through a system of debt-bondage to a new class of intermediaries, itinerant traders who plied their way along the rivers and purchased cured latex and supplied household goods. Isolated and with little access to public services, tappers survived through a combination of latex production and subsistence farming. Poverty is the norm amongst rubber them, with high levels of malnutrition, illiteracy, and diseases such as malaria and lieshmaniasis.

During the 1970s, the already precarious lives of rubber tappers came under further pressure from the advancing cattle front, part of the government's drive to 'integrate' the region into the mainstream economy. Business interests from São Paulo used hired gunmen and violent tactics to grab land from local populations. In southern Acre, a rural trade union movement was started in the 1970s by activists such as Wilson Pinheiro and Francisco 'Chico' Mendes to oppose this invasion. They developed a strategy of peaceful resistance, called an empate or stand-off, in which men, women, and children confronted laborers hired by ranchers and logging companies to clear the forest and attempted to persuade them to leave. It was a highly effective tactic: between 1976 and 1988, 45 empates reputedly saved more than one million hectares of forest from destruction (Mendes 1989). 
At the same time, Amazonia was coming under the international spotlight. From 1983, a network of environmental activists based in the U.S. started to monitor the impacts of development schemes funded by multilateral banks in the region. This culminated in a campaign against the World Bank's sponsorship of the Polonoroeste program, and led to the temporary suspension of loans in 1985, pending reformulation of the project to include provision for local conservation and development initiatives.

\section{Rural trade union activists developed a highly effective strategy of peaceful resistance to ranchers and logging companies who tried to clear the forest.}

As democratization gathered pace in Brazil, the Rubber Tappers' Council (CNS) was set up in 1985, the year that marked the formal end of military rule. By this time it had become evident that the rubber tappers' survival ultimately would depend on developing a longer-term strategy to manage their natural assets in a fashion that would both preserve the forests and strengthen people's livelihoods. With official development policies for Amazonia coming in for intense criticism, the time was ripe to develop an alternative model. The CNS and environmental activists thus began to formulate a proposal for extractive reserves, loosely modeled on the concept of indigenous reserves (Indian reservations in the U.S.) or protected areas for the exclusive use of indigenous groups.

Chico Mendes had become world renowned, receiving two international environmental awards for his work, including the UN Global 500 prize, and in 1987 he addressed the annual meeting of the Inter-American Development Bank (IDB) in Washington, DC. Soon after this visit to the U.S., the World Bank and the IDB both formally endorsed the extractive reserve proposal. That same year, Brazil's agrarian reform ministry created a legal instrument by adapting existing landreform legislation to set up 'extractive settlement projects' (PAEs) under the jurisdiction of INCRA. Ten private rubber estates were expropriated under Brazil's National Land Reform Program, to form PAEs covering a total of 900,000 hectares with some 3000 families. The authorities dragged their heels on the issue of setting up extractive reserves.

In December 1988, Chico Mendes was murdered at his home in southern Acre by local cattle ranchers. The resulting international outcry drew together diverse groups fighting for conservation and social justice, now increasingly perceived as two sides of the same coin (Keck 1995). The out-going administration of President Sarney rushed through legislation to allow the creation of extractive reserves.

The 'extractive reserve' was legally instituted early in 1990 under the auspices of a new department within the national environmental control agency (IBAMA), known as the National Centre for the Sustainable Development of Traditional Peoples (CNPT). Four federal extractive reserves were set up, covering over two million hectares. Since then, another fourteen federal extractive reserves have been decreed, covering a further two million hectares, and several states have taken steps to create locally administered units (Brazil 2002). ${ }^{2}$ Six of Brazil's 18 federally 
administered extractive reserves are home to a total of some 18,500 rubber tappers. Other notable cases include the babaçu nut gatherers of eastern Amazonia, and the movement to set up community-based floodplain fisheries management schemes in 'lake reserves' along the Amazon River.

The extractive reserve was a major policy innovation, since it officially incorporated local populations for the first time into the process of natural resource management. Until then, extractivists had remained politically 'invisible'. Their recognition represented a major conceptual break from the crude protectionist principles of the past that assumed all human presence in conservation areas to be inherently harmful to the environment. Rubber tappers set up local associations to help design and implement an environmental management plan for each reserve, to serve as the basis for a 60-year lease contract between CNPT/IBAMA and the reserve population. The local associations then sub-lease rubber stands to individual households. Land transfers to outsiders are prohibited, as are destructive forms of asset-use such as clear-felling of trees. Areas that had previously comprised common property resources, governed very loosely and informally by local populations, and thus vulnerable to appropriation by outsiders, would now be transformed into clearly defined legal units to be administered by extractive populations jointly with government agencies under a new form of cooperative, private usufruct.

The four federal extractive reserves initially set up in the early 1990s - Chico Mendes and Alto Juruá in Acre, Rio Ouro Preto in Rondônia, and Rio Cajarí in Amapá - were earmarked for financial and technical support under the 'G7 Pilot Program to Conserve the Brazilian Rain Forest' (PPG7), which was officially launched at the Houston Summit of 1990. Some US\$9 million was granted for 1995-99 to implement the four reserves (which until then existed only on paper), and a second five-year grant of the same size was approved from 2000. With foreign funding, and support from the Ministry of the Environment and other authorities, a number of major steps have been taken to transform these units from 'paper reserves' into viable concerns (CNPT 2000).

Measures so far have included demarcation and legalization of reserve boundaries, as well as baseline socio-economic and biodiversity surveys. In addition, there have been improvements in production, transport, health, and education infrastructure. In view of the huge areas covered by the reserves (almost one million hectares in the case of the reserve named after Chico Mendes) and their dispersed population, some 80 community centers have been built to act as meeting points. On these four reserves, seven local associations and five cooperatives have been set up and training given to local leaders in basic production and management skills. Apart from the four supported through the PPG7, other federal and state extractive reserves have received little, if any, financial support either from Brazilian authorities or outside donors.

\section{Current Challenges Facing Extractive Reserves}

The extractive reserve is, in theory, an ingenious solution for the problem of protecting inhabited forests. In order to make it viable in practice, however, a number of hurdles must be overcome. At the time of writing, there has been no detailed, systematic, independent evaluation of the performance of extractive reserves. Yet research suggests that extractive reserves face several 
major challenges in their quest for sustainability: (1) defending protected areas from illegal invasions as well as internal abuse; (2) generating higher household incomes through diversification of productive activities; (3) harnessing and strengthening social capital on the reserves; (4) creating a more favorable macro-policy environment; and (5) rewarding forest stewardship through non-market as well as market incentives. This section discusses each of these in turn.

\section{Defense and vigilance}

The immediate challenge faced by the rubber tappers and other extractivists has been to protect their new reserves from abuse, whether by outsiders or insiders. In the past, violent threats from cattle ranchers and loggers undermined security of tenure and induced tappers to engage in shortterm, destructive activities such as slash-and-burn farming or to abandon their plots altogether. These were rational responses in view of the fact that it was impossible to guarantee a long-term, secure income flow under such conditions. After their successful resistance to land-grabbing through the empates led by Chico Mendes and others, it was expected that the legal recognition of collective land rights together with a system of vigilance would discourage such short-term practices. The reserves would thus avoid a 'tragedy of the commons' scenario in which the land is treated as open-access. Community-based monitoring systems have been set up on the four reserves and around 400 reserve inhabitants have been trained and are paid as environmental wardens to police their areas. The passage of the federal 'Environmental Crimes Law' in 1998 has also made IBAMA sanctions more effective.

The main danger comes from outsiders undertaking illegal timber extraction, but the wardens check for abuse by reserve dwellers as well. In terms of territorial defense and protection, the existence of extractive reserves as an official conservation unit, together with a grassroots monitoring system, seems to have been effective. Satellite images from 1990 and 1998 show that forest loss on the four reserves remains very low, ranging from 0.23 percent (Alto Juruá) to 3.7 percent (Rio Ouro Preto). The losses are accounted for largely by subsistence farming and some cattle raising. These figures compare very favorably with deforestation levels for the states in which these reserves are located: nine percent for Acre and over 20 percent for Rondônia. Furthermore, rates of deforestation on the extractive reserves have been falling since they were established (CNPT 2000).

\section{Boosting household incomes}

A second requirement for reserves to be sustainable in the long term is enhanced incomegenerating capacity. This would provide economic incentives for rubber tappers to participate actively in collective resource governance, and help persuade them to stay on the reserves. Research data show that extraction of latex and Brazil nuts remains the mainstay of people's livelihoods on the four reserves. They constitute complementary parts of an 'agro-extractive' production cycle. Rubber tapping takes place during the dry season (April-December) while subsistence agriculture and nut gathering are undertaken during the wet months (DecemberMarch). 
There are two opposing schools of thought regarding the long-term feasibility of extractivism. The first sees it as an archaic remnant of traditional society that is essentially exploitative and traps people in poverty. Extractivists are seen as unable to compete with 'modern' plantation and synthetic products, especially in the case of rubber, forcing them into agriculture or off the land altogether (Homma 1994). The second stance questions this assumption of linear, evolutionary decline, arguing instead that potential economic returns from extractivism are considerable, comparing favorably with those from subsistence farming and cattle raising. Market-based strategies, in this view, can reconcile forest conservation and development (Gradwohl and Greenberg 1988; Anderson 1990; FOE 1992). More efficient exploitation of native rubber and Brazil nuts would underpin the new strategy (Allegretti 1994a, 1994b; Anderson 1994). In addition, this school of thought highlights the social roles performed by extractivists as they supply vital ecological services to the wider community (Emperaire 1996).

Since the heady days of the early- and mid-1990s, it has become apparent that rubber and Brazil nuts on their own are unlikely to generate adequate levels of income to support households or contribute significantly toward project overheads. Competition on world markets from Bolivia has seriously undermined production of Brazil nuts on extractive reserves, still a mainstay which complements income from rubber. Brazil's neighbor is able to produce nuts more cheaply due to a system of vertical integration of production, economies of scale, and labor exploitation including use of migrant Brazilian workers (Assies 1997). At the same time, Amazon rubber production has declined in the face of competition from Malaysian rubber and synthetic substitutes, while government subsidies were withdrawn. The price of latex fell from US\$1.80 per $\mathrm{kg}$ in 1980 to US\$0.40 per $\mathrm{kg}$ in 1992, while Amazonian rubber as a proportion of national production declined from 85 percent to 28 percent over the same period. These trends suggest that the first, pessimistic scenario might be an accurate prediction.

\section{Despite growing support to traditional extractive production, it is now widely agreed that additional, diversified forms of production are urgently needed.}

In 1998, however, under pressure from civil society, the federal government re-introduced subsidies for Amazon latex through the 'Chico Mendes Law'. Funds are channeled through rubber processing factories, which pay suppliers of the raw material over 50 percent more than the market price. The state of Amazonas also has established its own scheme for 1500 families in 86 communities, which pays rubber tappers directly through their associations, although these are not organized into extractive reserves. Such measures have been instrumental in boosting rubber production and value-added tax receipts as well as in persuading rubber tappers to return to the reserves from nearby towns where they had sought informal sector employment (Gazeta Mercantil 2001).

Improvements in latex production techniques also have been introduced, targeting niche markets such as surgical goods, aircraft tires, and computer mouse pads. New products such as 'organic 
leather' (sheets of cotton coated in latex) have been created, and used to make clothes, accessories, and car seat covers. Small factories have been set up on various reserves to process rubber, Brazil nuts, and heart-of-palm. There were early but generally ill-fated efforts to improve the efficiency of Brazil nut production on the Chico Mendes reserve, funded by a range of external agencies (including the Ford Foundation, Cultural Survival, WWF, and NOVIB) and efforts to market high-profile specialty products such as Ben and Jerry's 'Rainforest Crunch' ice cream. Brazil's federal government has also provided further financial support to agroextractivist activities through special credit lines. Yet despite this support to traditional extractive production, it is now widely agreed that additional, diversified forms of production are urgently needed.

There are plenty of examples of relatively successful attempts at developing alternative, sustainable activities in Amazonia in the field of agroforestry, albeit on a small scale (Hall 1997a; Smith et al. 1998). On the four reserves, over 170 tree nurseries have been set up, along with seed distribution systems and individual and community gardens. Studies are underway to explore the potential for expanding production of agroforestry and other non-timber forest products, including fruit pulp, medicinal and cosmetic plants, handicrafts, aromatic oils, Brazil nut biscuits, and heart-of-palm. Commercial contracts have been signed with a range of private and non-governmental organizations to assist in the marketing of these goods, and extractive reserves have been represented at many national and international trade fairs (CNPT 2000).

In a related development in March 2002, the 24,000 hectare Chico Mendes agro-extractivist settlement project, adjacent to the extractive reserve in southern Acre, was given a seal of approval by the Forest Stewardship Council (FSC) for its community forest management scheme. FSC certification, started in 1995, now covers five percent of the world's working forests (Conroy 2001). In Brazil, a rapidly growing network has emerged to satisfy the thriving niche market for certified timber (FOE 2001). Agroforestry and selective timber extraction are beginning to offer alternative economic options and to discourage internally induced deforestation by the reserve population (Vianna 2002). It is predicted that this could boost the annual incomes of rubber tappers by some US\$1500 a year per household (FOE 2002).

There is growing official commitment to integrating extractive production into regional economic development strategies, particularly in states such as Amapá and Acre that have environmentally sensitive political administrations. In April 2002, for example, the government of Acre launched a business agency to stimulate the production and marketing of 'green' products such as heart-of-palm, guaraná (a tree fruit used widely in the Brazilian Amazon to make a stimulating, high-caffeine drink), and Brazil nuts. The agency hopes to attract some US\$12 million in funding over four years from central government and multilateral sources.

It is evident, however, that the reserves face many formidable obstacles, including the high transaction costs associated with setting up production in the Amazon, collectively nicknamed 'the Amazon factor' in popular parlance. Problems include distance from urban markets, inadequate quality control, perishability of tree products, market saturation at given points for popular fruits such as cupuaçú, power cuts affecting refrigerated warehouses, and the lack of ongoing technical and financial support (Smith et al. 1998; Richards 1997; Plotkin and Famolare 1992). Furthermore, poor management capacity has on occasion undermined economic potential. 
For example, the nut-processing cooperative in Xapurí, Acre, serving the Chico Mendes reserve and funded by large foreign donations, in the past suffered from severe mismanagement (Hecht 1994; Hall 1996, 1997a). Given these problems critics have accused the extractivist movement of creating 'unrealistic expectations' based on 'environmental interventionism', and of shamefacedly using extractive reserves 'as a way of attracting foreign investment' (Homma 1994, 51-3).

\section{Strengthening social capital}

A third vital issue relating to the sustainability of extractive reserves is how far it is possible to strengthen 'social capital' so as to enable the local population to perform the functions for which it is responsible under this new model. Social capital refers to the networks of relationships and values that bind people together in forms of collective action, both within groups (bonding capital) and with other groups (bridging capital). Strengthening the weak organizational skills of reserve populations is a vital prerequisite for carrying out key reserve management activities, like vigilance and monitoring against external and internal abuses, and for forming alliances and negotiating with other government agencies, non-governmental organizations, the private sector, and international donors. As noted above, local vigilance has been effective in limiting deforestation on the reserves. Project monitoring missions have noted progress in strengthening community centers (World Bank 1997, 1998).

Outside observers sometimes assume that extractivists are akin to the 'noble savage' homogenous, egalitarian, and imbued with a spirit of collective action for the common good. During the early struggles against land grabbers, there was indeed a strong collaborative spirit of working together against the common external enemy. Yet in the longer term, many factors conspire against the permanent attainment of such ideals. Populations are widely scattered over huge areas, with the nearest neighbors often being several days away on foot or by river. Families settle in individual households, each with its rubber stands, frequently having to relocate because of seasonal flooding. There are few nuclear communities, and it is not uncommon for individuals to go for years without seeing close friends or relations, such are the obstacles of distance and poor communications. The installation of short-wave radios in some reserve community centers has helped to overcome these barriers.

The social structure of the rubber economy traditionally has been based on vertical ties of patronclientage and debt-bondage between tappers and estate owners or intermediary merchants, rather than on horizontal bonds of solidarity. Landowners did their utmost to maintain their workers in conditions of poverty, dependence, and ignorance, backed by violence in the event of any protest from below (Mendes 1989). Until the empates of the 1970s and 1980s - which took place only in southern Acre, around Xapurí - there had been no history of organized struggle by tappers against the brutal conditions under which they lived. This was what inspired Chico Mendes and his colleagues to start a rural union movement in 1975.

Democratization and unionization have opened up new rifts along party political lines, however, creating additional conflicts of interest amongst local rubber-tapper groups (Cardoso 2002). Traditional patronage may also be replaced by new forms of favoritism. There is evidence to suggest that some rubber-tapper communities, which are better organized politically and loyal to 
the CNS leadership and Workers' Party, may benefit disproportionately from new economic projects over which the CNS has decision-making control, placing other reserve members at a disadvantage (Hecht 1994; Hall 1997a, 1997b). This could exacerbate the already unequal distribution of household wealth within the reserves, leading to further resentment and disunity. Such developments could undermine the formation of social capital and collective resource governance on extractive reserves, unless new forms of organization can be instituted to overcome this obstacle.

\section{The macro-policy environment}

Historically, the macro-policy environment of official Amazon settlement and occupation has been dismissive of traditional production technologies such as extractivism. It is now widely recognized in Brazil that Amazon development policies have encouraged widespread destruction of the region's natural asset base, as a result of the deforestation induced by cattle ranching, commercial logging, mining, and unplanned or badly planned farmer settlement. This process is likely to continue, however, as infrastructure development plans officially valued at US $\$ 180$ billion are implemented under the Avança Brasil ('Forward Brazil') program over the coming decade (Brazil n/d-a). Designed to stimulate economic development in the industrial, agricultural, mining, and timber sectors, and to integrate the Brazilian Amazon into continental markets through Mercosul, this is likely to accelerate substantially current rates of forest loss (IPAM 2000; Laurance et al. 2001).

In this context, the positive externalities generated by conservation units such as extractive reserves are becoming increasingly apparent and are being officially acknowledged for the first time. In its Amazon development policy statement (Brazil 1995), the Brazilian government recognizes the interdependence of economic, social, and ecological dimensions of the environment and the need to incorporate local populations into resource management. The importance of protected areas for conserving genetic diversity and other ecological functions is highlighted in official proposals for a national biodiversity policy (Brazil 2000). A new National System of Conservation Units, which entered the statute books in 2001, incorporates the 'extractive reserve' as a form of sustainable development unit.

Thus there is evidence of a gradual change in official perceptions, both within and outside Brazil, regarding the potential contribution of Amazonia's traditional and extractivist populations to the process of sustainable economic development. Yet specific instruments for rewarding the providers of ecological services remain ad hoc. As discussed below, systematic mechanisms are required to internalize the environmental benefits generated by extractive reserves, so as to reward them for preventing deforestation and for their longer-term stewardship of ecosystem services.

\section{Rewarding forest stewardship}

Internalization mechanisms can be broadly divided into market-based mechanisms of environmental services and the use of public resources to reward non-market provision of 
environmental services. Market-based mechanisms have already been discussed at length above. The Brazilian government and NGOs have been actively involved in assisting reserve associations and cooperatives to explore marketing possibilities for non-timber forest products and for sustainably harvested (FSC-certified) timber. Consumer demand for these products reflects a desire to support ecologically sound production processes, and the resulting 'green' price premia in national and international markets can represent a modest but significant way for producers to internalize some fraction of the 'positive externalities' they generate through forest stewardship. At the same time, an important side-benefit of such initiatives is that they can raise public awareness of the importance of environmental services, such as biodiversity conservation and carbon sequestration, thereby helping to set the stage for more supportive public policies.

Since many of these commercial activities are embryonic, it is difficult to judge their long-term viability in the Amazon context. Yet it seems unlikely that locally generated, market-based extractive revenues will ever fully compensate rubber tappers for the ecological services performed by the reserves. It seems inevitable, therefore, that the onus will fall on public institutions to provide complementary financial support to reward forest stewardship. This is likely to require funding from both central government and international sources.

In terms of Brazilian public policy, various existing mechanisms could be more effectively harnessed. For example, fiscal instruments could be sharpened to favor conservation (Haddad and Rezende 2002). The Fundo Constitucional de Financiamento do Norte (FNO) a subsidized credit scheme introduced under the 1988 Constitution to finance small-scale agriculture in Amazonia, benefited some 120,000 borrowers from 1989-2000. In 1999, about 24,000 farmers received FNO loans worth over US\$200 million (Andrae and Pingel 2002). However, the distribution pattern of FNO funds has been questioned (see below) and there is evidence to suggest that the scheme could be better designed and implemented to reach extractivist and agroforestry groups.

The government is obliged by law to redistribute a proportion of federal income - tax revenues through state and municipal 'participation funds'. These were designed to compensate for biases as the result of poor local levels of economic activity and small tax bases in conventional central government mechanisms for allocating revenues. By including environmental quality indicators among the criteria, states and municipalities that support conservation activities such as extractive reserves could receive a greater share of these revenues. A first step in this direction was taken when the Brazilian Senate approved a proposal to earmark two percent of the state participation fund to states according to their area in protected and indigenous reserves. Worth some US\$18 million altogether, it was due to become operational in 2002.

Brazil's rural land tax was originally designed to discourage speculative and non-productive use of land by penalizing owners who kept their land idle. 'Productive use' is defined as conversion to farming or pasture, while standing forest is considered 'unproductive' and taxed accordingly at higher rates. Extractive reserves currently fall into the latter category and hence are penalized for their lack of 'productivity' (Haddad and Rezende 2002). This provision has encouraged proprietors to convert large forested areas to pasture to reduce their tax liability. In the Amazon context, there is an urgent need for the land tax law to be modified to acknowledge the potential economic value of standing forests in terms of both market-based agroforestry as well as non- 
market environmental benefits. Indeed, the law could be reoriented to reward forest stewards through tax breaks and concessions.

Another available tool is the 'ecological value-added tax' (ICMS-E) which has been applied successfully in the states of Minas Gerais and Paraná in central and southern Brazil (May et al. forthcoming). The ICMS-E allocates 2.5 percent of value-added tax revenues to compensate municipalities that have standing forests in protected areas, and it has been shown to be effective in encouraging the expansion of conservation units. Its impact could be enhanced further by increasing the ecological share of tax allocations. This could be a useful tool to strengthen extractive reserves, although states with a weak commercial tax base would still need other options, such as the municipal participation fund discussed above. In some municipalities, however, large landowners have been the prime beneficiaries of the tax, whereas in others poor rural households that manage their forests collectively have been prioritized. If extractive reserves are to benefit from this mechanism, there would have to be a clear political commitment from local government to this end, and greater transparency in the allocation of such tax revenues.

A major initiative to provide rural producers with financial incentives to reduce deforestation has been the government's recent Sustainable Development Program for Rural Family Production in Amazonia (Proambiente). Small producers engaged in conservation activities, including reforestation and cultivation of perennial tree crops, receive subsidized loans and compensation payments through an 'environmental service fund'. An explicit aim of the program is to increase the rate of carbon sequestration in Amazonia, where deforestation currently releases an estimated 200 million tons of carbon every year, three times the amount generated by the burning of fossil fuels in the country. Although this program is targeted not at extractive populations but at individual smallholders in Amazonia, it sets a precedent that could be applied more widely especially if Brazil manages to agree on a position with regard to the inclusion of standing forest within the Clean Development Mechanism (CDM) of the Kyoto Protocol.

As these examples reveal, there is increasing interest within Brazil in exploring ways of using fiscal mechanisms to internalize the environmental benefits of conservation and development efforts, such as extractive reserves. To date, however, most financial support for natural asset building and environmental protection in Amazonia has come from foreign sources. Until 1995, when the PPG7 got off the ground, the four federal extractive reserves existed only on paper. A PPG7 grant of US\$9 million (renewed in 2002) has underpinned their operationalization, with government counterpart funding of around ten percent. Without such external support, it is most unlikely that the reserves would have reached their present stage of development.

It can reasonably be argued that the PPG7 and similar forest conservation projects supported by the World Bank, the Inter-American Development Bank, bilateral agencies, and NGOs, are vehicles for internalizing environmental benefits. In terms of promoting species preservation, climate control, and carbon sequestration, it could be said, pure market mechanisms are not sufficient and it is the duty of the international public sector to seize the initiative and directly reward forest dwellers. Yet the amounts involved, are minor (if not insignificant) when compared to the volumes of public and private investment for economic development activities that accentuate deforestation. In the case of the PPG7 at any rate, the hope is that pilot initiatives 
will stimulate the dissemination of valuable lessons for promoting resource conservation and development, while helping to leverage government policies in a more environmentally-friendly direction.

A further possibility for external support is the international funding under the CDM of the Kyoto Protocol on climate change. Forests act as biological 'sinks' for carbon-dioxide emissions, mitigating the process of global warming and thus performing a valuable environmental service for humanity. The 1997 Kyoto Protocol requires industrialized countries who sign it to accept binding targets to reduce greenhouse gas emissions. Countries need not achieve these reductions solely by taking direct measures to reduce domestic emissions. Instead, they may achieve these targets indirectly by paying other countries to undertake net emission-reducing activities, such as the planting of new trees. The CDM would allow for sales of carbon credits generated by humaninduced changes in land use and management (Brown et al 2001). In Brazil's case, it has been argued that reduced-impact logging and avoidance of deforestation (more than reforestation) have tremendous potential for yielding carbon benefits (Fearnside, 2001a).

It appears likely that the role of Brazil's extractive reserves (and other conservation units such as National Forests) - in avoiding deforestation, controlling anthropogenic disturbances such as forest fires, and managing forest-use - could qualify as legitimate carbon-reducing activities under the CDM. However, during climate change negotiations the Brazilian Ministry of Foreign Affairs has rejected the suggestion that standing forests (as well as plantations) should be included in the CDM. Avoided deforestation was excluded from the CDM in the first commitment period of the Kyoto Protocol (2008-2012), but the issue could be revived later. Reasons offered for the Brazilian government's stance vary from concerns about the undermining of national sovereignty and fears about the 'internationalization' of the Amazon to holding out for higher carbon-trading prices. Paradoxically, major international environmental NGOs have also opposed the inclusion of Brazilian avoided deforestation in the CDM on the grounds that it would alleviate pressure on the USA to reduce its own carbon emissions (Fearnside 2001b).

Although public resources offer some scope for internalizing the ecological benefits of extractive reserve management, there are implementation and distribution issues which have to be faced. The funds made available to support extractive reserves have generally been considered 'participatory', with close involvement of grassroots organizations in their design and execution. Projects funded under the auspices of the PPG7, including extractive reserves and agroforestry schemes, are portrayed as having been 'demand-driven', considered a positive feature and an indicator of democratic processes (World Bank 2001). 'Demand' may reflect the evolution of strong social capital capable of articulating felt needs. That is, projects benefit those who have sufficient political connections and influence to impact decision-making. It is an open question, however, whether such 'demand' reflects the needs or interests of local resource users themselves, as opposed to outsiders such as NGOs and politicians with their own agendas. As noted above, the allocation of resources for some extractive projects has been subject to political bias (Hecht 1994; Hall 1996). Similarly, local managers have been known to manipulate project funds to further their own electoral ambitions (Hall 1997a). The rich have no monopoly over corruption. 
Micro-finance schemes also have been widely used as a form of social welfare in Brazil to subsidize political allies. Although such schemes have disbursed quite large amounts, their impact on poverty alleviation has been questioned. High rates of loan default have been recorded (50-70 percent) while wealthier borrowers have captured the lion's share of subsidies. Borrowers tend to be regarded as 'beneficiaries', as political patronage often dictates loan policy and there is scant regard to financial or technical soundness (Hall 1997a; Andrae and Pingel 2001; World Bank 2001). Clearly, if public policy instruments are to be more equitable and effective as vehicles for internalizing environmental benefits, their design and execution will have to be streamlined.

There are further potential problems in using official bilateral and multilateral assistance as compensatory mechanisms. Donors still operate largely within the confines of the standard project cycle. Their programs tend to be limited in duration, with fixed, predetermined objectives and quantitative indicators of progress. This format is not ideal for supporting long-term processes in which variables and objectives may change during implementation. Donor funds are also typically characterized by high overhead costs and slow execution. In the case of the PPG7, for example, overall administrative costs account for 40 percent of actual spending, and after seven years the Pilot Program had spent just 29 percent of committed funds (Indufor Oy and STCP 2000). ${ }^{3}$ Generating additional funds is therefore only part of the answer. Spending funds promptly and efficiently is an even greater challenge.

\section{Conclusion: The Future of Extractive Reserves}

The extractive reserves in Brazilian Amazonia were born of the rubber tappers' opposition to a rapidly advancing army of predatory loggers, land speculators, and cattle ranchers in search of quick profits. This army, like most armies in a state of open conflict, had no concern whatsoever for the environment - let along for respecting and preserving the natural asset base upon which local populations depended to sustain their livelihoods. The people themselves had to seize the initiative. Had they remained passive in the face of this onslaught, it would have been only a matter of time before the rubber stands were gradually clear-felled and the forest dwellers forced off the land into urban penury. The fact that the local people managed to put a halt to deforestation in certain areas of Amazonia is testimony to their resolve and determination, as well as to the logistical and political support they received from key Brazilian NGOs and unions and from international campaigning in the wake of the 1980s 'decade of destruction' and the murder of Chico Mendes. ${ }^{4}$

Winning this battle was difficult in one sense, yet easy in another. Having a common enemy united extractive populations against the destroyers of the Amazon, their short-term survival providing a common purpose, a clear goal. But the challenge of turning extractive reserves from 'paper protected areas' into self-sustaining units of 'productive conservation' (Hall 1997a) is undoubtedly the biggest battle of all. Since the mid-1990s, significant achievements have been made on various fronts. In the reserves, reforestation at the hands of outsiders has been reduced to a minimum through effective local policing. Decentralized management gradually is being implemented, with the setting up of local community associations and capacity-building through special training programs. Economic strengthening and diversification is taking place through 
improvements in traditional production as well as new ventures in agroforestry and community forests.

However, there are still serious potential problems to be faced. These include limited markets for forest products, their vulnerability to price fluctuations, and the generally high transaction costs of establishing such ventures in Amazonia. Moreover, the difficulties of inducing selfgovernance in hitherto poorly educated, geographically isolated, and socially fragmented traditional populations should never be underestimated. Even if environmental and social stability are attained in the medium- to long-term, economic self-reliance is in most cases probably unrealistic, unless it includes transfer payments to forest stewards in return for the environmental benefits generated through their activities.

\section{The challenge of turning extractive reserves into self-sustaining areas of 'productive conservation' is undoubtedly the biggest battle of all.}

Some analysts have warned of the dangers of creating a negative dependency of extractive reserves on outside funding, arguing that this removes their incentive to become self-reliant. This danger undoubtedly exists, but there is a strong counter-argument in favor of financially compensating conservationists for the environmental services that they provide. The expansion of 'productive conservation' initiatives in Brazil is bringing about a gradual change in official perceptions in this respect. It is becoming recognized that traditional populations have borne most of the costs of conserving natural assets and providing environmental services, but have reaped relatively few of the benefits. Federal and state governments have moved to establish fiscal and other instruments to help internalize these benefits. These include targeted credit lines, price support for strategic products such as native rubber, technical assistance, and provision of social welfare services. New tools such as 'green' taxes and special environmental funds could also be harnessed to support extractive reserves.

The international aid community has provided major assistance through such programs as the PPG7, and additional support has been forthcoming through the non-governmental sector. Preliminary lessons are emerging from these programs, although it would be premature to draw definitive conclusions at this stage. One clear lesson has been that it is dangerous to make unfounded assumptions about the availability of stable markets for forest products. Another is the need for greater investment at the early stages of project design and implementation in capacity building in financial and administrative matters, both for NGO staff and community managers, in order to avoid mismanagement and wasted resources.

The extractivist movement is now well established in Brazil's national policy framework. Following in the wake of the rubber tappers, other extractivist groups have kept up the pressure for federal intervention to protect threatened ecosystems and develop jointly managed reserves. The governance of key natural assets in a growing number of areas in Brazilian Amazonia depends on co-management operations being successfully implemented and sustained. National and international institutions, working with local stakeholders, have a responsibility to assist in 
this process. Federal extractive reserves have benefited from international aid, but there is a growing number of small reserves at state level which are in desperate need of support. These remain largely 'paper reserves' that urgently require basic physical and social infrastructure, as well as investment in production, marketing, and administration. In addition, overseas organizations could argue more strongly the case for international transfer payments through such mechanisms as the CDM of the Kyoto Protocol. International NGOs should target their resources and expertise in these key areas in order to help make extractive reserves a viable policy instrument for sustainable development. These lessons of the Brazilian experience are relevant elsewhere in the world, wherever natural assets are to be governed by local resource users. 


\section{Endnotes}

${ }^{1}$ Many of these enterprises, especially in the livestock sector, were subsequently discovered to have been fronts for land speculation and corruption. For example, a mere $16 \%$ of funded cattle ranches were found to be commercially viable, leading to the conclusion that most such enterprises had been fronts for obtaining cheap credit that was then diverted into other areas of economic activity, such as urban real estate speculation and personal consumption (Gasques and Yokomizo 1985).

2 The federal government has proposed to protect a further 2.3 million hectares of forest in Pará state, where mahogany is under threat of extinction (Brazil n/d-b; Hall 1997a; McGrath 2000; Pinto 2002).

3 To its credit, this figure was 100 percent in the case of the extractive reserves component.

4 'The Decade of Destruction' is the title of the documentary film series on Amazonia by British director Adrian Cowell. See also his book of the same title (Cowell 1990). 


\section{References}

Allegretti, Mary (1994a) 'Reservas Extrativistas: Parâmetros para uma Política de Desenvolvimento Sustentável na Amazônia'. In O Destino da Floresta: Reservas extrativistas e o desenvolvimento sustentável na Amazônia, edited by Ricardo Arnt. Rio de Janeiro: Relume Dumará.

(1994b) 'Policies for the Use of Renewable Resources: The Amazon Region and Extractive Activities.' In Extractivism in the Brazilian Amazon: Perspectives on Regional Development, edited by Miguel Clusener-Godt and Ignacy Sachs. Paris: UNESCO.

Anderson, Anthony (1990) Editor. In Alternatives to Deforestation: Steps Towards Sustainable Use of the Amazon Rain Forest. New York and Oxford: Columbia University Press.

(1994) 'Extrativismo Vegetal e Reservas Extrativistas'. In O Destino da Floresta:

Reservas extrativistas e o desenvolvimento sustentável na Amazônia, edited by Ricardo Arnt. Rio de Janeiro: Relume Dumará.

Andae, Silvio, and Kathrin Pingel (2002) 'Rain Forest Financial System: The Directed Credit Paradigm in the Brazilian Amazon and its Alternative.' Free University of Berlin, Institute of Latin American Studies. Unpublished paper.

Assies, Willem (1997) 'The Extraction of Non-Timber Forest Products as a Conservation Strategy in Amazonia.' European Review of Latin American and Caribbean Studies 62: 33-53.

Becker, Bertha (1982) Geopolítica da Amazonia. Rio de Janeiro: Zahar.

Becker, Bertha, and Paulo Egler (1992) Brazil: A New Regional Power in the World Economy. Cambridge: Cambridge University Press.

Bourne, Richard (1978) Assault on the Amazon. London: Gollancz.

Branford, Sue, and Oriel Glock (1985) The Last Frontier: Fighting Over Land in the Amazon. London: Zed Press.

Branford, Sue, and Jan Rocha (2002) Cutting the Wire: The story of the landless movement in Brazil. London: Latin America Bureau.

Brazil (n/d-a) Avança Brasil: Development Structures for Investment. Brasília: Ministry of Development, Industry and Foreign Trade, Ministry of Planning, Budget and Management and Brazilian Development Bank-BNDES.

(n/d-b) 'Manifesto pela criação da reserva extrativista das ilhas do Lago de Tucuruí.' 
(1995) Integrated National Policy for the Legal Amazon-Brazil. Brasília: Ministry of the Environment.

(2000) Política Nacional de Biodiversidade: roteiro de consulta para elaboração de uma proposta. Brasília: Ministry of the Environment.

(2002) Reservas Extrativistas na Amazonia. Brasília: IBAMA. (Available on the worldwide web at http://www2.ibama.gov.br/resex/amazonia.htm)

Brown, Katrina, and Sérgio Rosendo (2000) 'Environmentalists, Rubber Tappers and Empowerment: The Politics and Economics of Extractive Reserves.' Development and Change 31: 201-227.

Brown, Sandra, Ghillean Prance, Norman Myers, Ian Swingland, and Robin Hanbury-Tenison (2001) 'Carbon Sinks for Abating Climate Change: Can They Work?' Unpublished paper.

Cardoso, Catarina (2002) Extractive Reserves in the Brazilian Amazon. London: Ashgate.

Cowell, Adrian (1990) The Decade of Destruction: The Crusade to Save the Amazon Rain Forest. NewYork: H.Holt.

Conroy, Michael (2001) 'Can Advocacy-Led Certification Systems Transform Global Corporate Practices? Evidence and Some Theory.’ PERI Working Paper Series 21. Amherst, Massachusetts: University of Massachusetts, Political Economy Research Institute.

CNPT (National Centre for the Sustainable Development of Traditional Peoples) (1998) Extractive Reserves: Business Opportunities Without Environmental Destruction. Brasília: CNPT/IBAMA.

(2000) Projeto Reservas Extrativistas: Relatório Final da $1^{a}$ Fase, 1995-1999. Brasília: CNPT/IBAMA.

Dreifuss, René Armand (2000) 'Strategic Perceptions and Frontier Policies in Brazil.' In Amazonia at the Crossroads: the Challenge of Sustainable Development, edited by Anthony Hall. London: Institute of Latin American Studies, University of London.

Emperaire, Laure (1996) Editor. In La forêt en jeu: L'extractivisme en Amazonie central. Paris: ORSTOM/UNESCO.

Fearnside, Philip M. (1993) 'Deforestation in Brazilian Amazonia: The Effects of Population and Land Tenure.' Ambio 22(8):537-545.

(2001a) 'The Potential of Brazil's Forest Sector for Mitigating Global Warming Under the Kyoto Protocol.' Mitigation and Adaptation Strategies for Global Change 00:1-19. 
(2001b) 'Environmentalists split over Kyoto and Amazonian deforestation.' Environmental Conservation 28(4):295-99.

FOE (Friends of the Earth) (1992) The Rainforest Harvest. London: Friends of the Earth. (2001) Certificação Florestal no Brasil: Alguna Dúvida? São Paulo: Friends of the Earth. (2002) 'Chico Mendes viveu no futuro.' São Paulo: Friends of the Earth. (Available on the worldwide web at http://www.amazonia.org.br/noticias/print.cfm?id=8768)

Gasques, José Garcia \& Clando Yokomizo, 'Avaliação dos Incentivos Fiscais na Amazônia. 'Brasília: IPEA. Unpublished paper.

Gazeta Mercantil (2001) 'Subsídio a borracha tem resultados positivos no Acre.' 7 November 2001.

Gradwohl, Judith, and Russell Greenberg (1988) Saving the Tropical Forests. London: Earthscan.

Gross, Anthony (1990) 'Amazonia in the Nineties: Sustainable Development or Another Decade of Destruction?' Third World Quarterly 12(3-4):1-24.

Haddad, Paulo, and Fernando Rezende (2002) Instrumentos Econômicos para o Desenvolvimento Sustentável da Amazônia. Brasília: Ministry of the Environment.

Hall, Anthony (1978) Drought and Irrigation in North-East Brazil. Cambridge: Cambridge University Press.

(1989) Developing Amazonia: Deforestation and Social Conflict in Brazil's Carajás Program. Manchester: Manchester University Press.

(1996) 'Did Chico Mendes die in vain? Brazilian rubber tappers in the 1990s.' In Green Guerrillas: Environmental Conflicts and Initiatives in Latin America and the Caribbean, edited by Helen Collinson. London: Latin America Bureau.

(1997a) Sustaining Amazonia: Grassroots Action for Productive Conservation. Manchester: Manchester University Press.

(1997b) 'Peopling the Environment: A New Agenda for Research, Policy and Action in Brazilian Amazonia.' European Review of Latin American and Caribbean Studies. 62:9-32.

(2000) 'Environment and Development in Brazilian Amazonia: From Protectionism to Productive Conservation' In Amazonia at the Crossroads: the Challenge of Sustainable 
Development, edited by Anthony Hall. London: Institute of Latin American Studies, University of London.

(2000) 'Environment and Development in Brazilian Amazonia: From Protectionism to Productive Conservation' In Amazonia at the Crossroads: the Challenge of Sustainable Development, edited by Anthony Hall. London: Institute of Latin American Studies, University of London.

Hecht, Susanna (1985) 'Environment, Development and Politics: Capital Accumulation in the Livestock Sector in Eastern Amazonia.’ World Development 13(6):663-684.

(1994) 'Decentralization, Women's Labor and Development in Extractive Reserves.' Unpublished paper.

Homma, Alfredo (1994) 'Plant Extractivism in the Amazon: Limitations and Possibilities.' In Extractivism in the Brazilian Amazon: Perspectives on Regional Development, edited by Miguel Clusener-Godt and Ignacy Sachs. Paris: UNESCO.

INCRA (Instituto Nacional de Colonização e Reforma Agrária) (1997) Atlas Fundiário do Brasil. Brasília: Instituto Nacional de Colonização e Reforma Agrária.

Indufor Oy and STCP (2000) Mid-Term Review of the Pilot Program to Conserve the Brazilian Rainforest. Brasilia: Indufor Oy and STCP.

INPE (Instituto Nacional de Pesquisas Espaciais) (2000) Deforestation data 1998-99. Brasilia: INPE. (Available on the worldwide web at http://www.inpe.br).

IPAM (Instituto de Pesquisa Ambientas da Amazônia) (2000) Avança Brasil: Os Custos Ambientais para Amazonia. Belém and São Paulo: Instituto de Pesquisa Ambientas da Amazônia (IPAM) and Instituto Socio-Ambiental (ISA).

ISA (Instituto Socioambiental) (2000) Povos Indígenas no Brasil 1996/2000. São Paulo: Instituto Socioambiental.

Keck, Margaret E. (1995) 'Social Equity and Environmental Politics in Brazil: Lessons from the Rubber Tappers of Acre.' Comparative Politics 27(4):409-424.

Laurance, William, Mark Cochrane, Scott Bergen, Philip M. Fearnside, Patricia Delamônia, Christopher Barber, Sammya D'Angelo, and Tito Fernandes (2001) 'The Future of the Brazilian Amazon.’ Science 291:438-439.

Lovejoy, Thomas E. (2000) 'Amazonian Forest Degradation and Fragmentation: Implications for Biodiversity Conservation'. In Amazonia at the Crossroads: the Challenge of Sustainable Development, edited by Anthony Hall. London: Institute of Latin American Studies, University of London. 
Mahar, Dennis J. (1989) Government Policies and Deforestation in Brazil's Amazon Region. Washington DC: World Bank.

May, Peter, Fernando Veiga Neto, Valdir Denardin, and Wilson Loureiro (2002) 'The 'Ecological' Value-Added Tax: Municipal Responses in Paraná and Minas Gerais, Brazil.' In Selling Forest Environmental Services: Market-Based Mechanisms for Conservation, edited by Stefano Pagiola, Joshua Bishop and Natasha Landell-Mills. London: Earthscan.

McGrath, David (2000) 'Avoiding a Tragedy of the Commons: Recent Developments in the Management of Amazonian Fisheries.' In Amazonia at the Crossroads: the Challenge of Sustainable Development, edited by Anthony Hall. London: Institute of Latin American Studies, University of London.

Mendes, Chico, with Anthony Gross (1989) Fight for the Forest: Chico Mendes in His Own Words. London: Latin America Bureau.

Nepstad, Daniel, Adriana Moreira, and Ane Alencar (1999) Flames in the Rain Forest: Origins, Impacts and Alternatives to Amazonian Fire. Brasilia: Pilot Program to Conserve the Brazilian Rain Forest.

Pinto, Lucio Flavio (2002) 'Intolerância na selva.' O Estado de São Paulo, 26 February 2002.

Plotkin, Mark, and Lisa Famolare (1992) Editors. In Sustainable Harvest and Marketing of Rain Forest Products. Washington: Island Press.

Ramos, Adriana, and João Paulo Capobianco (1996) Editors. In Unidades de Conservação no Brasil. São Paulo: Instituto Socioambiental (ISA).

Richards, Michael (1997) Missing a Moving Target? Colonist Technology Development on the Amazon Frontier. London: Overseas Development Institute.

Schmink, Marianne, and Charles Wood (1992) Contested Frontiers in Amazonia. New York: Columbia University Press.

Schneider, Robert (1992) Brazil: An Analysis of Environmental Problems in the Amazon. Washington DC: World Bank.

Slater, Candace (2002) Entangled Edens: Visions of the Amazon. Berkeley and London: University of California Press.

Smith, Nigel, Jean Dubois, Dean Current, Ernst Lutz, and Charles Clement (1998) Agroforestry Experiences in the Brazilian Amazon: Constraints and Opportunities. Brasília: The Pilot Program to Conserve the Brazilian Rain Forest/World Bank. 
Vianna, Virgílio (2002) 'Seringueiros, certificação e desmatamento.' Folha de São Paulo, 15 April 2002.

World Bank (1997) 'Pilot Program to Conserve the Brazilian Rain Forest, Extractive Reserves Project, Mid-Term Review Mission.’ Brasilia: World Bank. Unpublished paper.

World Bank (1998) 'Program to Conserve the Brazilian Rain Forest, Extractive Reserves Project, Supervision Mission.’ Brasilia: World Bank. Unpublished paper.

World Bank (2001) Estudo Sobre os Fundos Sociais Ambientais Apoiados Pelo Banco Mundial no Brasil. Brasília: World Bank. 